\title{
NORMAS E INSTRUÇõES PARA PUBLICAÇÃO
}

A Revista Brasileira de Climatologia, instrumento de divulgação científica da Associação Brasileira de Climatologia, publica artigos científicos originais, notas técnicas, revisões bibliográficas, artigos especiais da área de Climatologia, com a condição de que sejam inéditos.

1. Os artigos especiais serão submetidos sob convite do Conselho Editorial. Nos outros tipos de publicação, ao menos um dos autores do trabalho deverá ser sócio da Associação Brasileira de Climatologia.

2. Os trabalhos serão submetidos via eletrônica, digitados em formato compatível com Word ou Open Office Writer, em idioma português, espanhol ou inglês, em folha de $18,5 \times 26,5 \mathrm{~cm}$ com margens superior e inferior de $1,60 \mathrm{~cm}$, margem esquerda de $2,50 \mathrm{~cm}$ e direita de $1,60 \mathrm{~cm}$, fonte Verdana 10 , espaço simples. O máximo de páginas será de 20 (vinte), incluídos tabelas, gráficos e ilustrações.

3. O trabalho submetido como artigo, deverá conter os seguintes tópicos: Título (em português, inglês ou francês); Resumo (máximo 2000 caracteres); Palavras chaves (máximo 5 palavras); Abstract ou Resummé (máximo de 2000 caracteres); Key words ou Mots clé ; Introdução com Revisão da Literatura e Objetivos; Material e métodos; Resultados e Discussão; Conclusões (ou combinação destes últimos), Agradecimentos, quando houver, e Referências Bibliográficas. Não há necessidade desta subdivisão para as notas e revisões, mas elas devem conter, obrigatoriamente, um pequeno resumo e o abstract ou resummé.

4. Os nomes dos autores deverão ser colocados por extenso, abaixo do título, um ao lado do outro e separados por vírgula, seguido de números que serão repetidos no rodapé, para especificações (Profissão, Titulação e Endereço).

5. As citações dos autores no texto deverão ser feitas com letras minúsculas seguidas do ano de publicação entre parêntese e em letras maiúsculas se a citação estiver entre parentes, conforme exemplos:

O balanço hídrico foi calculado segundo o método de Thortnthwaite e Mather (1957) ........enquanto que em água pode representar 100\% (JARVIS, 1975).

6. As Referências Bibliográficas deverão ser apresentadas de acordo ABNT, como nos exemplos:

CAMARGO, A. P. de. Contribuição para a determinação da evapotranspiração potencial no Estado de São Paulo, Bragantia, Campinas, v. 21, n. 12, p, 163-213, 1962.

OMETTO, J. C. Bioclimatologia vegetal. São Paulo: Ceres, 1981. 400 p.

COCHRAN, W. G. The stimation of sample sign. In: Sampling Techniques. 3« ed. Nova York: John Willey, 1997, Cap. 4 p. 72-90.

7. As tabelas deverão ser numeradas com algarismos arábicos com cabeçalho ou legenda explicativas na sua parte superior e construídas de modo a serem inteligíveis. Linhas horizontais devem aparecer para separar o título do cabeçalho e este do conteúdo, além de uma linha no final da tabela. Linhas verticais não devem ser usadas.

8. Desenhos, gráficos e fotografias serão denominados Figuras, tendo o número de ordem em algarismos arábicos e o título na sua parte inferior. Todas deverão estar em formato digital, preferencialmente no formato JPG, em resolução adequada ao tamanho da imagem. Não serão aceitas figuras repetitivas de tabelas. As figuras serão impressas em tons de cinza, salvo se o autor arcar com os custos extras.

9. Cada trabalho submetido será enviado a dois representantes do Conselho Editorial (pareceristas) que emitirão um relatório orientando os editores sobre a qualidade do trabalho. Os editores sempre manterão contato com o(s) autor(es) quando julgarem necessário, para as devidas correções, até que se tenha uma decisão sobre a oportunidade de publicá-lo ou não, consultado os pareceristas que subsidiarão os editores em sua tomada de decisão. Os trabalhos serão publicados em ordem de aprovação.

10. A critério dos editores, os trabalhos que não se enquadrarem na área de Climatologia, não serão aceitos e devolvidos ao(s) autor(es), sem passar pelo trâmite editorial.

11. Na submissão, o(s) autor(es) deverá (ão) deixar claro o tipo de publicação (artigo, nota técnica ou revisão bibliográfica) que deseja(m) para o trabalho.

12. Os conceitos e afirmações contidos nos artigos serão de inteira responsabilidade do(s) autor(es), mas o Conselho Editorial se resguarda o direito de sugerir alterações. 


\section{Consultores desta edição}

Ana Maria de P. M. Brandão

Cleuza Zamparoni

Deise Fabiana Ely

Denise Maria Sette

Edson Cabral

Emerson Galvani

Ercília Torres Stenke

Francisco Mendonça

Inês Moresco Danni-Oliveira

João Lima Sant'Anna Neto

José Tadeu Garcia Tomasselli

Luci Hidalgo Nunes

Maria da Graça Barros Sartoni

Margarete C. C. T. Amorim

Marta Celina Linhares Salles

Miriam Ramos Gutjahr

Zilda de Fátima Mariano

Washington Assunção 